\title{
A phenomenological approach to the ethics of transplantation medicine: sociality and sharing when living-with and dying-with others
}

\author{
Kristin Zeiler
}

\author{
Linköping University Post Print
}

Tweet

N.B.: When citing this work, cite the original article.

The original publication is available at www.springerlink.com:

Kristin Zeiler, A phenomenological approach to the ethics of transplantation medicine: sociality and sharing when living-with and dying-with others, 2014, Theoretical Medicine and Bioethics, (35), 5, 369-388.

http://dx.doi.org/10.1007/s11017-014-9307-3

Copyright: Springer Verlag (Germany)

http://www.springerlink.com/?MUD=MP

Postprint available at: Linköping University Electronic Press

http://urn.kb.se/resolve?urn=urn:nbn:se:liu:diva-111601 


\title{
A phenomenological approach to the ethics of transplantation
}

\section{medicine: sociality and sharing when living-with and dying-with others}

\author{
Kristin Zeiler \\ Department of Thematic Studies - Technology and Social Change, Linköping University \\ 58183 Linköping, Sweden; \\ The Swedish Collegium for Advanced Study, Uppsala University, Uppsala, Sweden.
}

\begin{abstract}
The original publication is available at
Kristin Zeiler, 2014. A phenomenological approach to the ethics of transplantation medicine: sociality and sharing when living-with and dying-with others. Theoretical Medicine and Bioethics 35(5):369-388.
\end{abstract}

DOI $10.1007 / \mathrm{s} 11017-014-9307-3$

Post-print version. Please quote only from the published version.

\begin{abstract}
Recent years have seen a rise in the number of sociological, anthropological, and ethnological works on the gift metaphor in organ donation contexts, as well as in the number of philosophical and theological analyses of giving and generosity, which has been mirrored in the ethical debate on organ donation. In order to capture the breadth of this field, four frameworks for thinking about bodily exchanges in medicine have been distinguished: property rights, heroic gift-giving, sacrifice, and gift-giving as aporia. Unfortunately, they all run into difficulties in terms of both making sense of the relational dimensions of postmortem and live organ donations and being normatively adequate in the sense of shedding light and providing guidance on ethical concerns when body parts are donated. For this reason, this article presents a phenomenological framework of giving-through-sharing, based on Maurice Merleau-Ponty's philosophy. This framework makes sense of relational dimensions of postmortem and live organ donation. It also sheds light on three highly debated concerns in organ donation ethics: indebtedness on the part of recipients, the fact that some live donors do not experience donation as a matter of choice, and the potentially painful experience of donors' relatives, who need to make decisions about postmortem organ donation at a time of bereavement. It can indirectly support what may be called a normalization of bodily exchanges in medicine.
\end{abstract}

Keywords: organ donation; phenomenology; sharing; relationality; embodiment; ethics. 


\section{Introduction}

Two ethical frameworks have dominated organ donation debates: property rights and giftgiving. Recent years have also seen a rise in the number of sociological, anthropological, and ethnological works on the gift metaphor in donation contexts [1-4], as well as in the number of philosophical and theological analyses of giving and generosity [5-8], which has been mirrored in the ethical debate on organ donation. In order to capture the breadth of this field, four frameworks for thinking about bodily exchanges in medicine can been distinguished: property rights, heroic gift-giving, sacrifice, and gift-giving as aporia, i.e., paradox. ${ }^{1}$ These frameworks represent four different ways of making sense of donation, draw on different conceptions of the relation between the self and the other, and give rise to different core ethical issues. Unfortunately, and as argued elsewhere, they also run into difficulties in terms of both making sense of the relational dimensions of postmortem and live organ donations and being normatively adequate in the sense of shedding light and providing guidance on ethical concerns when body parts are donated [9].

In this article, I present the alternative framework of giving-through-sharing, which is based on Maurice Merleau-Ponty's phenomenological work. I argue that this framework can shed light on three debated concerns in organ donation ethics: indebtedness on the part of recipients, the fact that some live donors do not experience donation as a matter of choice, and the potentially painful experience of donors' relatives, who need to make decisions about postmortem organ donation at a time of bereavement. The giving-through-sharing framework also meets the two criteria above: it makes sense of the relational dimensions of postmortem and live organ donation and is normatively adequate in the sense of shedding light and providing guidance on some ethical concerns when body parts are donated. While not offering a normative obligation to donate, it can shed light on the potential beauty and problems of the

\footnotetext{
${ }^{1}$ Briefly, what has been labeled the property rights framework for organ donation introduces an ownership conception of the body, connects to discourses of ownership and individuals' property rights in other areas, and emphasizes the individual's property right over her or his body, such as the rights to use, transfer, and manage her or his organs, according her or his own preferences. Furthermore, proponents of this framework often, but do not always, see property rights as including income rights, which allows for the sale of organs. In contrast, the heroic gift-giving framework conceptualizes organ donation as a caring response to others in need. It emphasizes the generosity of donors who donate without any financial benefits and the supererogatory, heroic dimension of this act, whereas the gift-giving as sacrifice framework brings to light the darker sides of organ donation, such as potential social pressure and emotional complexities when one needs to make decisions regarding organ transplantation, for example, when in shock and suffering bereavement after a loved one's death. It sees donation as a hard-wrought sacrifice and a personal offering for the good of others. Finally, the gift as aporia framework (where aporia means paradox, as in Jacque Derrida's work [7]) discusses the gift without return, and how concerns about repayment, or indeed, awareness of the gift as a gift, dissolves the act of gift-giving and reduces gift-giving to a gift exchange and to a matter of the human propensity to give-and-reciprocate in circles of gift-debt-countergift. See [9].
} 
interaction between self and other and indirectly support a normalization of bodily exchanges in medicine.

The article is divided into four parts. First, I present Merleau-Ponty's rethinking of embodiment, perceptual experience, and the relation between self and others via his analysis of the bodily nature of the human being-in-the-world [12]. I also discuss the understanding of giving and being-given in this philosophical perceptive, argue that we should preferably conceptualized these phenomena in terms of giving-through-sharing, and point at the potentials and limits of the understanding of giving-through-sharing when the framework is applied to organ donation. This will be my main example, but the framework can also be applied to, for example, tissue and gamete donation. Second, I discuss how the framework of giving-through-sharing can shed light on the relationality and relational interdependence in live and postmortem organ donation in three cases. I argue that the giving-through-sharing framework allows us to elaborate a logic of sharing that, more adequately than the logic of gift-giving, can avoid the problem of a potentially harmful indebtedness on the part of organ recipients. I also discuss how this framework allows us to make sense of the sociality of pain, fear, and agony in cases of intrafamilial and friend-to-friend donation. This is valuable if we are to better understand some parents' description of donation to their ill child in non-choice terms. It allows us to understand these donations in terms that go beyond the dichotomy of choice vs. coercion. Furthermore, the giving-through-sharing framework allows us to acknowledge the darker side of postmortem organ donation in a more substantial way than is possible when using the sacrifice framework. Third, I introduce Peter Gordon's notion of "a normative image of humanity" $[13$, p. 5] and discuss possible the normative contribution of the giving-through-sharing framework. Fourth, I point at some limits of this framework, but argue that its advantages outweigh its disadvantages.

\section{Merleau-Ponty's phenomenology of the body}

In Phenomenology of Perception, Merleau-Ponty offers a phenomenological account of bodily existence that challenges mind-body as well as subject-object dualisms. My body, he emphasizes, is always both an object for others and my lived reality, yet, I exist neither as a thing nor as consciousness. Focus is on my lived body, a mind-body unity, experiencing and acting in a specific situation. My lived body is my lived relation to a world immersed in meaning, which is opened up to me through my bodily senses and made meaningful to me in interactions with others, which also means that subjectivity is understood as embodied and embedded. My lived body is not just "a thing in the world, but a way in which the world 
comes to be," as Drew Leder put it [12, p. 25], and as a body, I act upon and perceive the world as a system of possibilities.

This formulation points at the close interrelation between perception, intentionality, and action in Merleau-Ponty's reasoning. Perception is understood as immediately and prereflectively organizing the world for certain purposes, such as the purpose of engaging with others and the world in an intelligible manner. It has to do not only with sensual experience, strictly speaking, but also with how we are directed in the world as embodied beings, and how we are "given" the world by others. Furthermore, perception is intersubjectively structured. This is the case because the world is furnished with meaning by others and infused with cultural significance. The world is understood as a shared world into which we are born and which others already inhabit and shape. How others make the world meaningful to us, together with us and we with them in our early years and onward, will inform how the world appears to us, even if we may come to see it differently at a later time.

The focus on intersubjectivity is far from unique to Merleau-Ponty's phenomenological work, but his approach has proven particularly useful in bringing out the bodily dimension of the connectedness and continuity between self and other. It has been used in analyses of how individuals, through habituation and repeated motor activity (mimicking) of others' bodily habits and gestures, can come to incorporate others' behavior patterns into their own body [15-17]. Along related lines, Gail Weiss discusses how body images are "construed through a series of corporeal exchanges that take place both within and outside of specific bodies" in engagement with others [18, p. 2]. While one's body image can be seen as personal, it is also continuously formed in interactions with others and is hence never only personal.

The phenomenological notion of intercorporeality has been used to denote the basic openness and non-discreteness of bodies and to highlight how bodily selves develop and come to be in relation to each other, in the above examples. ${ }^{2}$ The point I wish to make, however, is that such intercorporeal exchanges, as they may be called, take place through a dynamic sharing of meaning on bodily levels of existence and co-existence. Consider how Merleau-Ponty uses the notion of being given, when he writes that the central phenomenon, at the root of both my subjectivity and my transcendence towards others, consists in my being given to myself. I am given, that is, I find myself already situated and involved in a physical and social world - I am given to myself, which means

\footnotetext{
${ }^{2}$ The term "intercorporeality" was used in Merleau-Ponty's posthumously published The Visible and the Invisible [19] in a discussion of how to rethink subjectivity. For more recent discussions of intercorporeality, see [16-18] and [20-23].
} 
that this situation is never hidden from me, it is never round about me as an alien necessity, and I am never in effect enclosed in it like an object in a box. [12, p.419] To be given to oneself is a description of the condition of human life. I am not separated from others and the world. However, if I am given to myself in the world, in relations with others, then this takes place through a basic sharing of one's being-in-the-world. In other words, the giving at stake is primarily not that in which I give away something to others for their keeping, but a giving-through-sharing that brings out the basic connectedness between self and other.

On the one hand, the giving-through-sharing at stake when we teach someone a new skill, or when we seek to make someone comfortable in a new situation by showing him or her how to act in it, can take place after reflection, in cases where the self has thought through how she engages with the other. On the other hand, and in most cases, we seem to give by sharing our mode of being-in-the-world on pre-reflective levels, without thinking about how we do so or that we are doing so. In this connection, Rosalyn Diprose [22] reworks MerleauPonty's understanding of our bodily style of being, i.e., our habituated mode of being-in-theworld that is formed in and through interactions with others, in light of Jacque Derrida's [7] gift conception (where neither giver nor recipient should recognize the gift as gift; otherwise, the gift will become part of a gift exchange, and its gift character, writes Derrida, will be dissolved). Our bodily style of being is characterized by an incorporation of the corporeal gifts of others that often are unintentional and remain unrecognized by both giver and receiver.

This indicates that the language of gift, used here, is broader than that of everyday usage. Furthermore, giving-through-sharing can have both positive and negative consequences for those involved in the process. Others' way of giving me the world as meaningful by sharing their mode of being may have detrimental consequences for me, and there may also be social asymmetries in these processes. Some others may also be remembered for their "gifts," whereas others may be forgotten, and there are asymmetries regarding which bodily subjects are positioned as having something to give-through-sharing. ${ }^{3}$

\section{Giving-through-sharing in organ donation}

It has been suggested that a successful explication of the gift metaphor in the context of organ donation needs to be based on a rich philosophical anthropology that offers a detailed analysis

\footnotetext{
${ }^{3}$ Cf. Diprose [22]. For an analysis of how others' way of giving us the world as meaningful by sharing their mode of being may have detrimental consequences for us, see Zeiler [24].
} 
of embodiment [25], and Merleau-Ponty's phenomenology of the body may seem like a particularly apt candidate in this regard. This, however, is a statement that needs to be qualified.

On the one hand, while there may be no difference between "learning a skill or inheriting someone else's kidney" in the sense that I am given new possibilities deriving from the other's bodily existence [22, p. 54], other differences need to be acknowledged. ${ }^{4}$ There may be good ethical reasons for donating body parts even when this involves serious risks to the health of the donor, but such risks often differ both in magnitude and quality from those involved in most everyday intercorporeal exchanges of bodily habits or skills. Furthermore, organ transfer takes place at specific moments in time, and the body part that is given is given away and no longer forms part of one's own body. The giving-through-sharing at stake in intercorporeal exchanges of bodily habits and skills, rather, denotes the continuous processes of becoming when the self reaches out towards and engages with others and the world.

On the other hand, if the focus in organ donation as well as in intercorporeal exchanges of bodily habits or skills is not on the single item that is transferred from one individual to another but on what makes the act possible at all, then the focus shifts back to the sharing of bodily existence as a basis for understanding both of these cases of bodily exchanges. The phenomenological understanding of giving-through-sharing encourages a shift in focus from the measurable body part that is transferred from one individual to another to shared embodiment. Furthermore, a phenomenological exploration of intercorporeal exchanges of habits, skills and ways of being-in-the-world and of organs focus on the socio-cultural-bodily dimensions of intersubjective meaning-making. At stake is a philosophical perspective that takes us beyond body-mind and nature-culture dualisms. Importantly, the phenomenological understanding of giving-through-sharing also makes clear that sharing does not imply melting into one. While others may share their bodily mode of being with me, the unicity of the individuals is not dissolved into sameness. Rather, the giving-through-sharing mode of existence brings to light how bodily subjects are constantly formed in relation to each other, how the self is not isolated from others, and how bodies may preferably be understood as sites of "intersection where various modes of embodiment play themselves out" [26, p. 241].

This intertwinedness of self and other is also at stake in organ donation, where the organ within, from another person, supports the self. This is Catherine Waldby's point when she discusses how organ and tissue recipients experience the transplant as other than them, as

${ }^{4}$ Cf. Zeiler [9]. 
coming from someone else, yet also theirs, and how recipients are compelled to understand their embodied identity as open to the other in a very concrete sense. Indeed, a successful transplantation requires an immunological and psychological accommodation to the posttransplant body, which will always bear traces of the donor. The intertwinement between self and other is something that donors and recipients may be constantly reminded of, because recipients' sometimes "precarious state of health is owed to an uncertain compromise between their body and another's" [26, p. 249], necessitating a continuous regime of immunosuppressive drugs. This is also one of the points in Margrit Shildrick's analysis of heart recipients' post-transplant experiences. Calling for a bioethics that makes sense of the otherness within in some heart transplant recipients' experiences and that challenges "the propriety - the completion and closure — of individual bodies," Shildrick discusses the opening to the other as ambiguous, uncertain, and part of intercorporeal life [27, p. 62].

\section{Making sense of relationality in organ donation}

How can the phenomenological reasoning on giving-through-sharing be used to make sense of the concerns of indebtedness, of intrafamilial donations, in which family members experience donation in non-choice terms, and of the potentially painful experiences of relatives who must make choices about postmortem donation during bereavement? To this I now turn, and my starting point in this endeavor is neither heroism nor property rights, neither sacrifice nor the paradox of gift-giving - the four frameworks mentioned in the introduction.

\section{The problem of indebtedness}

Critics of the concept of the gift in organ donation sometimes underscore that organ donation understood as the gift of life may create or strengthen recipients' feelings of indebtedness [1, 4]. This is the case because of the phenomenon, or logic, if one prefers, of gift-giving that Marcel Mauss aptly described and which includes an obligation to give, receive, and reciprocate the gift $[28,3]$. The logic is as follows: gift-giving is a social endeavor that creates, shapes, and sustains social relations; failure to receive the gift (if one does not have special reasons to not receive a gift) implies rejecting the relation, just as one-way gifts result in imbalances in the relation. In order to restore the relation to equilibrium, recipients need to return the gift, at the right time and in the right way.

This logic can be much more elaborated, but one aspect of it is particularly noteworthy here. The gift is different from both windfalls and contracts, as Paul F. Camenish puts it, and has a "continuing identification with the donor's will or intention in giving it" [29, p. 2]. If I 
accept the gift, Camenish explains, I enter into a moral relation with the donor and cannot do whatever I like with the gift (such as willfully destroy it) without this having implications for our relation - should the other find out. When accepting the gift, I acknowledge the giver as someone who has made the effort to give (if I do not simply pretend to accept the gift as gift). The giver is acknowledged as someone who has something worth giving and is capable of giving good gifts. ${ }^{5}$

Camenish argues against the common idea that the best gift is one without any strings attached. Instead, he states, "part of the moral relation grounded in gift is the recipient's willingness to live graciously with an imbalance" to her or his favor, at least temporarily [29, p.12]. There is beauty in the character of the gift, precisely in the way that gifts should not be carefully balanced with counter-gifts, but be enjoyed. Yet, the moral of the logic of the gift is difficult to avoid: if I want to keep a good relation with the giver, there are certain tacit rules or limits to what I can do with it. In cases of organ donation, and if the organ is conceptualized as the gift, recipients, by accepting this gift, enter into a gift relation in which they may graciously live with the imbalance or-as is the concern-experience a detrimental indebtedness towards the donor because an organ is a gift that is difficult to reciprocate. That which first was understood as grace may transform into its opposite.

Contrast, now, the logic of gift-giving with what I will tentatively call the logic of giving-through-sharing. The logic of gift-giving builds on the idea that I have something valuable that I give to another, which results in an imbalance in the relation, temporarily. The other person then feels the need to restore the balance by giving something valuable back, and through such giving and returning we show appreciation of our relation, or vice versa. At stake, indeed, are gift exchanges. However, if the starting point is sharing, and if human existence is understood as characterized by giving-through-sharing, then this allows us to shift focus from giving-and-giving-back to the manifold ways in which we share existence as a basic prerequisite for human life.

What I propose is not a naïve idea of humanity sharing basic conditions and therefore being able to share organs. A framework of sharing needs to be able to account for asymmetries in sharing. ${ }^{6}$ Nevertheless, and returning to the problems with the gift-giving logic, the logic of gift-giving may have negative effects on the recipient that the alternative

\footnotetext{
${ }^{5}$ A qualification is also needed: some forms of giving may be of the potlatch kind, where someone gives in order to make a certain status statement, but this is no reason to assume that gifts cannot also be given because the giver wishes to promote the recipient's well-being and because she or he enjoys seeing the other thrive.

${ }^{6}$ See Zeiler [9].
} 
logic of sharing can avoid or at least diminish. If the point is not that givers first have something valuable that they give to another (who then needs to reciprocate the gift at the right time and in the right way), but instead, is the various ways in which we continuously share bodily existence with others, then the logic of gift-giving seems to lose some of its grip. Arguably, the adequate response to someone giving-through-sharing his or her way of engaging with the world by making it familiar to us, is not on the level of gift-debtcountergift. Instead, the adequate response could be to continue to share bodily existence with this person and others in various ways. In contrast to the logic of gift-giving, the appropriate response to sharing may be gratitude for shared existence rather than indebtedness and the giving back of what was first given or its equivalent.

This does not imply that bodies are understood as shared resources over which the individual has no decision-making authority, or that we need to turn to individual property rights in order to claim the individual's decision-making authority over her or his body. Indeed, another basis for the idea of individual decision-making authority over one's body has been developed from within a phenomenological account of bodily being-in-the-world where my body is something that I may experience as that which I have (when suffering illness and pain, I may relate to my hurting arm as an 'it', this hurting arm that I have), and as my centerfor-existence, i.e., as that which I am (in most everyday situations when I am healthy). This opens the door to another way of making sense of individual decision-making authority over one's own body: it can be based on an argument about identity [30]. While my lived body is formed in relations with others, interdependent and interconnected, it makes sense to claim that I have decision-making authority over my body because it is who I am-and that this holds even if I am continuously given in relations with others. As a bodily subject, my body is my center of existence, and for this reason I should have decision-making authority over whether, for example, I donate my body or parts of it to others.

\section{Living-with-others: the suffering other}

The giving-through-sharing framework also sheds light on concerns in relation to intrafamilial live donation, specifically, the social pressures that make potential donors feel that they must donate. This debate has been fueled by empirical research on parental live organ donation, where parents describe this donation in non-choice terms, i.e., as the only alternative when their child is severely ill, as natural for them, and as something that they felt was necessary [31-34]. Scholars have perceived this to be ethically troubling. If parents experience donation as non-choice, can they still say no to donation, or are they "forced" to donate owing to their 
relationship to their child? Within this debate, some have described the parent-child relation as "inherently coercive" [31, p. 377].

The giving-through-sharing framework, grounded as it is in Merleau-Ponty's phenomenological account of bodily being-in-the-world, offers conceptual tools for making sense of this situation via a discussion of the phenomenon of sharing that takes us beyond the dichotomy of choice vs. coercion. Below, I present this reasoning in several steps, and discuss how it is anchored within the giving-through-sharing framework.

Interest in the phenomenon of sociality has informed phenomenological studies of the experience of identifying, and the immediacy with which we identify, the other as another locus of experience, and of how the other's facial and vocal expressions, body language, and posture can generate in us an immediate (though more or less subtly) felt experience [35-37]. ${ }^{7}$ Merleau-Ponty's take on this can be exemplified with his discussion of the case of an encounter with an angry man. In this encounter, he says, I need not try to "recall the feelings which I myself experienced when I used these gestures on my own account ... and what is more, I do not see anger or a threatening attitude as a psychic fact hidden behind the gesture, I read anger in it. The gesture does not make me think of anger, it is anger itself" [12, p. 214]. The other's anger manifests itself through facial, gestural, and interoceptive changes, and I can see and sense his anger with my body without needing to think about what it feels like to be angry.

For the point I will make about parental live organ donation, it is useful to keep three ideas together. First, Merleau-Ponty rejects the idea that perception is an act of judgment, in which I compare my gestures when angry with those of others, and instead, understands perception as an "opening out onto and engagement with otherness" and "an active interrogation in search of form," as Nick Crossley puts it [38, p. 26]. Perception is a dialectical relation between perceiver and that which is perceived.

Second, Merleau-Ponty understands the lived body as "our expression in the world, the visible form of our intentions" $[15$, p. 5] and adheres to the view that bodily expressions such as emotions (most often) are publicly available as embodied behavior, expressed in sentient engagement with others and the world. Emotion, then, is a way of relating to others and the world, and the other's emotion is available to me precisely because the other's subjectivity is embodied and embedded in the world, just as is mine. It is expressed bodily; its meaning is

\footnotetext{
${ }^{7}$ Despite their differences, phenomenologists also tend to agree that intersubjectivity does not only concern faceto-face encounters, but is also at stake in perception, emotion, self-awareness, or tool-use. For a good overview of different phenomenological positions on this, see Zahavi [35].
} 
"arrayed" all over the expression [12, p. 216]; and typically, it is not neatly kept within the physical boundary of my body but carries meaning beyond these boundaries and affects others. In this way, we are "joined to others by emotion" and emotion "shapes and is shaped by our interactions with others" [38, p. 45]. This can also be formulated in terms of bodily expressions forming the shared space in between self and other. As put by Lisa Folkmarson Käll, while an individual may express anger, this anger unfolds in "shared expressive space" between them, and how it does so depends on the specificity of this encounter [39, p. 71]. The angry individual may express his anger differently depending on who he encounters, where the encounter takes place, and how the other responds, just as the individual encountering this angry person may respond differently — without thinking about this — depending on the context of the encounter and past interactions with this other. Importantly, bodily expressions that unfold in shared space can affect how both the self and the other relate to each other and experience the situation.

Third, Merleau-Ponty examines the role of our habitual manner of engaging with others and the world - a manner that emerges from the body's capacities and from habituated expressive postures, ways of feeling, acting, and interacting. He labels this a bodily style of being, and suggests that certain attitudes and patterns of action and being can come to function as our taken-for-granted way of being-in-the-world and integrate its affective, sensory-motor, and perceptual dimensions. In this sense, having a bodily style of being is a matter of "being a body and having a history" [40, p. 161], and my style of being puts some restrictions on me in terms of what actions, gestures, etc., will be easy for or come easily to me without implying any determination. This is the case, with Merleau-Ponty's example, with a man who has built his life upon an inferiority complex for many years. Through habituation, by being repeatedly enacted, certain attitudes and behavior patterns can form this man's perception, emotion, and action and become his default mode of being-in-the-world, his taken-for-granted mode of existence. This habitual mode of being-in-the-world can inform his perception. If his inferiority complex has become an integrated part of his mode of being, he may come to perceive social gatherings as fearsome and-if this has become his taken-forgranted bodily style of being - without thinking about it, he may withdraw from such gatherings. In this way, past interactions with others can shape how the subject perceives present ones, what actions stand out as being for him.

Consider, now, parental live organ donation in the light of a combination of these three ideas. When a parent sees her child's curled up body, shaking shoulders, and eyes filled with tears after an acute illness episode, she can be immediately and prereflectively aware of the 
child's sadness and perceive his agony. Because of the basic openness between self and other and the way bodily expressions unfold in shared space between self and other, it would hardly be surprising if the way the child's fear unfolds and is responded to in the parent-child shared space affect both of their experiences of the situation. Furthermore, while there is no determinism regarding whether the agony and fear that unfold between a parent and a child will cause them to draw nearer, parent and child may have developed-over time-a bodily style of being together, where the parent is attuned to the suffering of the child, and where her habitual mode of being is one of seeking to alleviate the child's suffering in various ways.

If emotions are not typically hidden within the self, but rather, unfold in the shared space between self and other, if parent and child live together and share experiences of the child's acute illness episodes, fear, hope, and agony, and if the parent when sharing these experiences responds in a caring way, then this way of responding to this specific other-the child - may come to be, through repeated behavior, part of the parent's bodily style of being. Just as in other cases in which we develop a bodily style of being, there is no determinism, but some actions will come easier for us than others, i.e., those that are in line with our bodily style of being. This being the case, and if the caring mode of existence has become part of the parent's bodily style of being - because the parent has interacted with the child over time, followed him to medical check-ups, sought to comfort the child when he has been in pain, guarded over the child during troubled sleep - it is also likely to inform the parent's perception of the situation and her possibilities for action just as was the case for the shy man. Indeed, owing to past interactions, this mode of being may have become the parent's bodily style of being, a style of being that causes her to see no other alternative than to care for the child in yet another way (through donation), as being for him.

This allows the temporal dimension to be added to the way self and other, face-to-face, can share expressive space and to how the emotion or pain that unfolds between them can form both of their modes of being-in-the-world. In such a case, descriptions of donation in non-choice terms make sense. Furthermore, something seems to get lost when such a parentchild relation is described as "coercive." Indeed, rather than such parental donation being "coerced," it may express what the parent really wants in this situation: to do what is needed to improve the child's health. No other alternative stands out as being within their grasp, but the reason need not reside in a coercive relation. It may instead be in how parent and child have shared the past, been formed in relation to each other, and how the past is drawn into the present and can anticipate some future actions more readily than others. 
This reasoning goes beyond a concern with choice vs. coercion, and brings in the bodily dimension of shared existence. By starting from the understanding of giving-through-sharing, from the way in which the self is open to others and the world and gives the world to others by sharing it, I have examined how this very sharing between parent and child can shape each of their modes of being in the world, and cause the parent to experience no other option than organ donation.

Two features of this reasoning are particularly noteworthy. First, the giving-throughsharing framework's focus on dynamic sharing of meaning on bodily levels of existence and co-existence over time, which I previously described as a difference between the understanding of being given in phenomenology of the body and organ donation (if organ donation is understood as taking place at specific moments in time), now becomes one of the strengths of this reasoning. The feature allows us to understand better what may set the condition for whether or not donation is seen as an alternative, or as the only alternative, precisely because it brings together embodiment, intersubjectivity, and how past interactions can form our present mode of being-in-the-world together with others. Second, the reasoning sheds light on Diprose's statement about limits to our "freedom to give." She writes, in a discussion of some concrete forms of bodily giving:

So the ethics of giving blood, gametes, sexual pleasure, or children to another is not decided on the basis of whether these gifts are alienable, unconditionally and universally, and therefore whether giving them put's one's freedom at risk. Rather, our freedom to give in any of these ways is limited by the habits and capacities we have developed as well as those of the bodies with whom we dwell, limits guided by the social signification of the corporeality in question. [22, p. 55]

In the case of intrafamilial live donation, one's bodily style of being also sets the limits to one's freedom not to give, even if there is no determinism or coercion at stake.

\section{Dying-with-others}

Consider also the concern typically voiced from the perspective of the sacrifice framework regarding the heroic gift-giving framework: that the latter is inadequate if we wish to make sense of the darker and more troubling sides of organ donation. Donation, it is stated, may be better understood as a sacrifice, in relation to acknowledging the bereavement of relatives when a loved one has died and the frustration that relatives may experience when asked to 
make decisions about postmortem organ donation at this point in time [41]. However, while the sacrifice framework brings forward these troubling dimensions of organ donation, the giving-through-sharing framework allows us to capture and depict in more detail why postmortem organ donation can be experienced as painful.

My starting-point this time is the phenomenological understanding of subjectivity as intersubjectively structured. Parts of this understanding can be expressed, in the language of (particularly feminist strands of) analytic moral philosophy, in terms of causally and constitutively relational selfhood. Causal relationality implies that selfhood is shaped, developed and possibly thwarted in relations with others. Throughout our entire lives, but more explicitly so during some periods (e.g., when we are very young, ill, or very old), we are interdependent and need "causal help" from others to develop as selves and to manage our everyday life. Constitutive relationality focuses on the social constitution of the self. It is present when it is held that early childhood relations constitute the very structure that gives us a sense of our self and when these relations are understood as parts of our way of being selves. Other selves not only contribute to one's meaning-making, but this shared meaningmaking is also constitutive of who one is. Both of these dimensions of relationality lie at the heart of the giving-through-sharing framework and its understanding of selfhood. Because of the way others continuously give-through-sharing the world to us, and indeed, because of how we ourselves are given in these relations, selfhood is intersubjectively structured and not only in a causal sense. The relation with others with whom we live forms part of our existence, and in this sense, the self is constituted by its relations with others.

I will now make a short detour to feminist phenomenological discussions and rereadings of Martin Heidegger's analysis of a human being's authentic relation to death, her being-towards-death, in order to discuss how the phenomenological understanding of selfhood described above can shed light on the potentially traumatic aspects of postmortem organ donation for relatives.

For Heidegger, being-towards-death reveals the human being's temporality and individuality, and how death is "ownmost" in the sense that nothing is more mine than my own death [42, p. 294]. Death reveals the inescapable finitude of human existence. While Heidegger accurately remarks that no one can die for me so that I will never die, feminist phenomenologists suggest that we may usefully consider death in the light of birth. What is needed, they suggest, is an examination of the ontological and ethical significance of birth as a limit that orients the self toward an other, who resists appropriation and who gives not only 
a wide range of possibilities but "gives me, brings me forth as an existent," as put by Lisa Guenther [43, p. 107].

Guenther calls this structure of natality "being-from-others" and argues that existence as the gift of the other implies that I cannot simply claim it as my own — and that not only birth but also death highlights the relational dimension of the human mode of being-in-the-world. Death, Guenther suggests, can be a "transformation and a partial continuation" of my relation to the world in those respects that affect others. While we will die alone in one sense, all of us leave "something behind - if only our naked and lifeless body - that is exposed to the response of others" [43, p. 113].

This point can be made more strongly and somewhat differently from the perspective of the giving-through-sharing framework. As discussed earlier, existence as the gift from another is a gift that is given by and through how we share existence- how others make the world meaningful to us and how we make it meaningful to them. It is also through these processes that the self's causally and constitutively relational aspects become evident. Now, if this reasoning on relational selfhood is taken seriously, it implies not only that birth has ontological significance (in the sense that a unique individual is brought into existence in the shared world of others) but that death does as well, and in a different way than that suggested by Heidegger. If one starts from the idea of a constitutively relational self, a person's death is not solely her or his own; it is also "the termination of the plurality of relations with which that person has been constituted," as Alison Stone puts it, and for this reason, death is shared [44, p. 210].

Stone does not make the connection to phenomenology of the body, but her reasoning fits well with the thoroughly relational understanding of the self just outlined. Because of the continuous giving-through-sharing that characterizes human co-existence, subjectivity is intersubjectively structured from the start, and our mode of being-together can be a constitutive part of who we each are. While it can be useful to differentiate between a basic intercorporeal openness between self and other that serves as a basis for the self as constituted by its social relations with others (the other's pattern of acting or interacting can, through repetition, become an integrated part of the self's mode of existence and co-existence) and the self's concrete interactions with others with whom one lives and shares everyday life, both dimensions are brought together in the point I want to make. Because of the basic intercorporeal openness and the everyday sharing of life in relations with family members and friends, selfhood is continuously intersubjectively formed, and our relations with such close others can form part of who we are. 
Thus, the giving-through-sharing framework is able to give significance to bereavement. Bereavement need not be less significant in human existence than the self's own death, and dying-with-others is not simply metaphorical but can be a very real breakdown of my previous existence. While there is an obvious asymmetry at stake in that the person who dies ceases to exist, and though those caught up in this death suffer loss and not the end of their own existence, death is, in Stone's words, "relational as a corporeal phenomenon that befalls human beings as bodies entwined as organisms, so that the loss of the one disables the other physically, makes their bodily functions seize up and collapse, more-or-lesstemporarily" [44, p. 370].

If the postmortem organ donation is conceived in light of the giving-through-sharing framework, the focus is on the connectedness and continuity between the self and the other that makes this act possible. But importantly, this focus acknowledges that making decisions in a bereavement process can be emotionally very difficult, because death is relational. In this way, the giving-through-sharing framework, more so than the sacrifice framework, is able to explicate why postmortem organ donation can be painful for relatives: the reason may have more to do with how the other is constitutive of the self, and vice versa, than with the giving away_ or offering — of a body part to someone else after a loved one's death.

\section{Normative guidance}

Before discussing what normative guidance the giving-through-sharing framework offers, it is useful to turn to the four mentioned frameworks in the introduction, i.e. those of property rights, heroic gift-giving, sacrifice, and gift-giving as aporia. This provides an idea of what normative guidance these different ethical frameworks can offer.

The property rights framework offers normative guidance by arguing that bodily exchanges should follow the normative implications of individuals' property rights in other areas. Debates center on whether one can have property rights over one's whole body or only parts of it, and whether property rights over one's own body also include income rights. ${ }^{8}$ For some who argue for income rights over one's body, the "solution" to the scarcity of organs is to be found in a market economy that balances supply and demand [10]. Others, who claim that we have property rights but not income rights over our bodies, instead conclude that each individual has the right to alienate body parts, but not to make money through this transaction. This latter position points at the blurring of the line between some versions of the property

\footnotetext{
${ }^{8}$ For a longer discussion of these frameworks, see Zeiler [9].
} 
rights framework and that of gift-giving. A property rights proponent may argue for the right to give her or his body part to another, based on her or his own inclination. Yet, the latter form of the property rights position also differs from that of the heroic gift-giving framework in terms of style of reasoning and focus. The heroic gift-giving framework draws its normative force from a logic of comparison, where organ donation is described as yet another way to act in a supererogatory manner and see to the benefit of others. Examples of this framework typically draw on the cultural imaginary—such as in the German campaign in which Superman flies over a city at night looking for people in need, and the text says, "Du kannst Du auch. Organspenden heisst Lebensretten"-rather than offering detailed philosophical arguments for why one should act generously for the benefit of others [9]. Although the campaign makes an appeal rather than an argument, the normative message is clear: organ donation is a way to save life and something we all can and should do.

In contrast, the sacrifice and the gift as aporia frameworks offer less normative guidance on whether, and if so, how, to increase donation rates. These frameworks seek instead to problematize that which takes place in organ donation, either by criticizing what is perceived to be a one-eyed focus on the generosity of giving or by pointing at the paradoxical character of gift-giving, where gifts easily become part of (and dissolve into) gift exchanges. The latter concern lies at the heart of Derrida's exploration of the difficulty in stepping outside the logic of gift-giving, and he examines the phenomenon of a gift without return, and, among other things, the possibility of conceptualizing the gift as unintentional. This last, however, seems less helpful when seeking to make sense of donors' experiences of live organ donation. $^{9}$

The foregoing makes clear that the normative guidance provided by these four frameworks differ in kind. At the same time, all of them function as spotlights that light up some (and different) ethical terrain. In this regard, the two latter frameworks do normative work - though not in the sense of stating that individuals should or should not donate. Instead, the sacrifice framework points at the potentially ethically problematic experiences of being asked to make decisions regarding organ donation at a time of shock and sorrow, whereas the gift as aporia framework questions our very conceptions of what it means to give, to give unconditionally, and to give ethically, and emphasizes that these issues require further exploration.

\footnotetext{
${ }^{9}$ This, of course, is not what Derrida himself tries to do. Rather, he explores the possibility to give without entering the cycle of debt and repayment.
} 
One more angle on the issue of normativity is helpful to consider before I turn to the giving-through-sharing framework. In his analysis of the 1929 debate between Ernest Cassirer and Martin Heidegger at Davos, Peter Gordon introduces the term a "normative image of humanity." Gordon describes the normative image of humanity as a more or less intuitively held notion that provides a sense of "mental orientation" for philosophical argument; it often takes the form of a deeply held belief, can be more or less argued for, and can "be a condition for think[ing] about ourselves at all" [45, p. 5]. He suggests that the core feature of Cassirer's normative image of humanity is the creativity that allows humans to freely create worlds of meaning and express themselves, while it is the finitude or thrownness of the human being that is the core feature for Heidegger. This is useful for untangling the possible normative contributions of different frameworks of bodily exchanges in medicine.

Now, the point I want to make via the term "normative image of humanity" is not to identify the essence of a humanity offering itself in its necessity. Instead, I use the term as an analytic tool in order to express core features of frameworks for thinking about bodily exchanges in medicine. If a normative image of humanity can be discerned within the property rights framework, I suggest that it is that of the individual who holds certain rights over her or his body - this is a core idea that serves as a condition for thinking about bodily exchanges from within this framework (see discussion in [9]). If there is a normative image of humanity, in the sense of certain recurrent ideas about human existence that provide a "mental orientation" within the giving-through-sharing framework, it is that of self and other understood as intertwined without merging into one. The focus is on a basic sharedness of human existence, in which the acts of one individual typically do not only affect that individual alone, and in which self and other are understood as connected, unique, and different.

This focus on connectedness and sharing could be used to down-play the extraordinary event of donation. Just as in the heroic gift-giving framework, such a line of reasoning would work by analogy. Human existence is understood as a matter of giving-through-sharing, and organ donation is one more way to do so. The focus, however, is not on the heroism, and the framework allows us to acknowledge that donation can be painful and detrimental to the self and the other. Indeed, the framework calls for a rethinking of the relation between self and other, where the focus is less on the individual's boundaries and more on that which takes place between self and other. This is also how this framework functions as a spot light: it sheds light on the potential beauty as well as problems of the interaction between self and other, rather than primarily on the individual who gives or the individual who receives. That 
said, there are also other possible implications in terms of a potential increase in the number of donated organs. The framework of giving-through-sharing could support what may be called a normalization of bodily exchanges in medicine. In the light of this framework, donations could be understood as yet another way in which we share our bodily existence with others, rather than as something unusual and exceptional. This may, in the long run, contribute to making organ donation less extraordinary and more common.

This reasoning is based on the analogy between the intersubjective structure of human subjectivity and the experience of connectedness and continuity with others, which allows us to understand transplantations as something that is not unusual or exceptional. Importantly, however, my point is not to argue that the giving-through-sharing framework fits all possible experiences but that it can help to think through certain common ethical concerns. While the giving-through-sharing framework can have implications in terms of a normalization of bodily exchanges in medicine, there are surely differences between live and postmortem organ donations and between different kinds of live organ donation; also, parental live kidney donation (as an example) may be experienced in different ways depending on how, why, and in what socio-cultural context one donates. Such differences need still to be accounted for.

Finally, the giving-through-sharing framework may function as a starting point for another kind of normative discussion, which I will only hint at here. Starting within this framework, one may add that human affliction and suffering are basically moral phenomena that can and should awaken us to a moral sense of care for the other that necessitates a caring response. This seems to be the case in Richard Zaner's analysis of experiences of being on dialysis when living with end-stage renal diseases, which, he suggests, are not only experiences of pain and disrupted modes of being-in-the-world. The person afflicted with end-stage renal disease, "as afflicted, is the presence to the other, nonafflicted person of a moral entreaty which is compelling to others precisely by its having been unasked for, by its having been neither chosen nor deserved" [46, p. 53]. This human affliction, he continues, can and should appeal to us to respond with care. Such an approach avoids the criticism of committing the naturalistic fallacy, commonly evoked by analytic moral philosophers and aimed at phenomenological approaches to normative ethics, but it does so by adding an idea that needs to be argued for: that human subjects should reach out for each other in caring acts, because of their way of being together and because of how affliction simply throws itself upon us, beyond any claims we may wish to make about justice. Still, even if one were to accept this reasoning, one would be left with questions, such as to what extent we should 
reach out for each other in caring acts: are there limits to what and under what circumstances we should respond to suffering others by donating parts of our bodies?

These are questions that go beyond the scope of the present article, but they usefully clarify the limits of the giving-through-sharing framework. On the one hand, while the suffering other can call us forth and call for action, there is no necessity in this regard and the framework does not offer a normative ethics position in terms of obligations to donate. On the other hand, the very focus on connectedness between self and other can allow for an attunement to other's suffering on the part of the self, which can make her or him more prone to caring acts than if the focus were kept on the individual her or himself. The framework may be combined with reasoning such as that of Zaner, but this would require a longer discussion of why human affliction should make us reach out for each other in particular ways.

\section{Why this framework is preferable}

In one of the few efforts to outline an ethics of organ donation on phenomenological grounds, Drew Leder suggests that an acknowledgment of the connectedness and continuity of human existence can enable us to understand organ donation as a positive confirmation of the way of things, i.e., of the fact that we are all being interconnected [47]. However, while helpful as a starting point, this is not enough. The giving-through-sharing framework needs to be combined with an analysis of who gives and who receives, and with the role of one's own unique embodiment in one's ways of engaging with others. This has been discussed elsewhere [9], and I will only add that because of its character, the giving-through-sharing approach will not help us put exact limits on what and when one should or should not give. And this does not only apply to this particular framework, but to all the frameworks of organ donation discussed here. ${ }^{10}$

The giving-through-sharing framework is apt if we wish to make sense of relationality and relational interdependence in organ donation. It is helpful in making sense of and shedding light on some of the recurring ethical concerns in these discussions - such as that of whether or not parents who experience donation as non-choice should be understood as forced to donate, and that of the potentially painful situation of postmortem organ donation for relatives. Furthermore, this way of thinking about organ donation is not part of the gift-giving logic, but rather of the logic of sharing. For those who are concerned about the consequences

\footnotetext{
${ }^{10}$ In this way, the property rights framework states that it is up to the individual to decide whether or not to donate, and the heroic gift-giving framework tells us that it is positive and heroic to give, but neither says anything about in what circumstances we may be ethically justified not to act in this way.
} 
of the gift-giving logic, yet do not want to recur to the property rights framework, the givingthrough-sharing framework offers an alternative logic. In this way, and alongside the gift as aporia framework, the giving-through-sharing framework notes how the logic of gift-giving becomes problematic. In contrast to the gift as aporia framework, which can be less apt for applying to, for example, certain forms of live organ donation given its conceptualization of gifts as preferably known neither to recipients nor givers, the giving-through-sharing framework is apt for thinking about different forms of bodily exchanges, where both donor and recipient are reflectively aware of the very concrete way in which they share existence. What I have explored with the formulation "giving-through-sharing" is whether and how the donation of an organ (the giving) can be understood as an expression of the connectedness and continuity between the self and the other, which is the very precondition of subjectivity itself (the sharing), and whether it is useful to think of the very phenomenon of giving as a matter of sharing. I hope to have shown, moreover, how the giving-through-sharing framework makes sense of relationality and sheds light on certain ethical concerns.

Finally, while the framework's main aim is to offer a tool for thinking differently about organ donation (as well as, for example, tissue, gamete, and blood donation), it also has implications for clinical work. It offers a philosophical basis for trying to understand why relational interdependence matters for how we talk about organ donation, and can result (in the long run and indirectly) in an increase in the number of donors: donation comes to be understood as one more way in which we share existence rather than as a rare and heroic act of supererogatory giving.

\section{Acknowledgement}

This article is part of my work as Pro Futura Scientia Fellow. I am very thankful to the Swedish Collegium for Advanced Study, Uppsala University, and Riksbankens Jubileumsfond for their financial support for this work.

\section{Reference list}

1. Scheper-Hughes, N. 2007. The tyranny of the gift: Sacrificial violence in living donor transplants. American Journal of Transplantation 7: 507-511.

2. Sque, M.S., S. Payne, and J. Macleod. 2007. Gift of life or sacrifice? Key discourses to understand organ donor families' decision-making. Mortality 11(2): 117-132. 
3. Fox, R.C., and J.P. Swazey. 2001. The courage to fail: A social view of organ transplants and dialysis. 3rd ed. Piscataway, NJ: Transaction Publishers.

4. Simingoff, L.A., and K. Chillag. 1999. The fallacy of the "gift of life." The Hastings Center Report 29(6): 34-41.

5. Hénaff, M. 2010. The price of truth: Gift, money, and philosophy. Stanford: Stanford University Press.

6. Wyschogrod, E., J.J. Goux, and E. Boynton, eds. 2002. The enigma of gift and sacrifice. New York: Fordham University Press.

7. Derrida, J. 1997. Given time: 1. counterfeit money. Chicago: The University of Chicago Press.

8. Schrift, A.D, ed. 1997. The logic of the gift: Towards an ethic of generosity. New York: Routledge.

9. Zeiler, K. 2014. Neither property right nor heroic gift, neither sacrifice nor aporia: the benefit of the theoretical lens of sharing in donation ethics. Medicine, health care and philosophy 17(2):171-181.

10. Dunham, IV, C.C. 2008. Body property: Challenging the ethical barriers in organ transplantation to protect individual autonomy. Annals of Health Law 17(1): 39-66.

11. Christman, J. 1994. Distributive justice and the complex structure of ownership. Philosophy and Public Affairs 23(3): 225-250.

12. Merleau-Ponty, M. 2006. Phenomenology of perception. London: Routledge.

13. Gordon, P. 2010. The continental divide: Heidegger, Cassirer, Davos. Cambridge, MA: Harvard University Press.

14. Leder, D. 1992. A tale of two bodies: The Cartesian corpse and the lived body. In The body in medical thought and practice, ed. D. Leder, 17-35. Dordrecht: Kluwer Academic Publishers.

15. Merleau-Ponty, M. 1964. The primacy of perception. Evanston, IL: Northwestern University Press.

16. Fuchs, T., and H. De Jaeger. 2009. Enactive intersubjectivity: Participatory sense-making and mutual incorporation. Phenomenology and the Cognitive Sciences 8: 465-486.

17. Zeiler, K. 2014. A philosophical defense of the idea that we can hold each other in personhood: Intercorporeal personhood in dementia care. Medicine, Health Care and Philosophy 17:131-141.

18. Weiss, G. 1999. Body images: Embodiment as intercorporeality. New York: Routledge. 
19. Merleau-Ponty, M. 1968. The visible and the invisible. Evanston, IL: Northwestern University Press.

20. Joas, H. 1983. The intersubjective constitution of the body-image. Human Studies 6: 197204.

21. Crossley, N. 1995. Merleau-Ponty, the elusive body, and carnal sociology. Body \& Society 1: 43-63.

22. Diprose, R. 2002. Corporeal generosity: On giving with Nietzsche, Merleau-Ponty, and Levinas. Albany: State University of New York.

23. Käll, L.F. 2013. Intercorporeality and the sharability of pain. In Dimensions of Pain, ed. L.F. Käll, 27-40. London: Routledge.

24. Zeiler, K. 2013. A phenomenology of excorporation, bodily alienation, and resistance: Rethinking sexed and racialized embodiment. Hypatia. A Journal of Feminist Philosophy 28(1): 69-84.

25. Svenaeus, F. 2010. The body as gift, resource or commodity? Heidegger and the ethics of organ transplantation. Journal of Bioethical Inquiry 7: 163-172.

26. Waldby, C. 2002. Biomedicine, tissue transfer, and intercorporeality. Feminist Theory 3(3): 239-254.

27. Shildrick, M. 2014. Visceral phenomenology: Organ transplantation, identity, and bioethics. In Feminist Phenomenology and Medicine, ed. K. Zeiler and L.F. Käll, 47-68. Albany: State University of New York Press.

28. Mauss, M. 1966. The gift: Forms and functions of exchange in archaic societies. London: Cohen \& West.

29. Camenish, P.F. 1981. Gift and gratitude in ethics. Journal of Religious Ethics 9: 1-34.

30. Mackenzie, C. 2001. On bodily autonomy. In Handbook of phenomenology and medicine, ed. S. Kay Toombs, 417-440. Dordrecht: Kluwer Academic Publishers.

31. Forsberg, A., M. Nilsson, M. Krantz, and M. Olausson. 2004. The essence of living parental liver donation-donors' lived experience of donation to their children. Pediatric Transplantation 8: 372-380.

32. Spital, A. 2005. More on parental living liver donation for children with fulminant hepatic failure: Addressing concerns about competing interests, coercion, consent and balancing acts. American Journal of Transplantation 5: 2619-2622.

33. Knibbe, E., E.L.M. Maeckelberghe, and M.A. Verkerk. 2007. Confounders in voluntary consent about living parental liver donation: No choice and emotions. Medicine, Health Care and Philosophy 10: 433-440. 
34. Zeiler, K., L. Guntram, and A. Lennerling. 2010. Moral tales of parental living kidney donation: a parenthood moral imperative and its relevance for decision making. Medicine, Health Care and Philosophy 13(3):256-233.

35. Zahavi, D. 2001. Beyond empathy: Phenomenological approaches to intersubjectivity. Journal of Consciousness Studies 8:151-167.

36. Colombetti, G., and S. Torrance. 2009. Emotion and ethics: an inter-(en)active approach. Phenomenology and the Cognitive Sciences 8: 505-526.

37. Kruks, S. 2001. Retrieving experience: Subjectivity and recognition in feminist politics. Ithaka: Cornell University Press.

38. Crossley, N. 1996. Intersubjectivity: The fabric of social becoming. London: SAGE.

39. Käll, L.F. 2009. Expression between self and other. Idealistic Studies 39: 71-86.

40. Singer, L. 1981. Merleau-Ponty on the concept of style. Man and World 14(2): 153-163.

41. Mongoven, A. 2003. Sharing our body and blood: Organ donation and feminist critiques of sacrifice. Journal of Medicine and Philosophy 28(1): 89-114.

42. Heidegger, M. 2008. Being and time. Malden, MA: Wiley-Blackwell.

43. Guenther, L. 2008. Being-from-others: reading Heidegger after Cavarero. Hypatia 23(3): 99-108.

44. Stone, A. 2010. Natality and mortality: rethinking death with Cavarero. Continental Philosophy Review 43(3): 353-372.

45. Gordon, P. E. 2010. Continental divide: Heidegger, Cassirer, Davos. Cambridge, MA: Harvard University Press.

46. Zaner, R. 1982. Chance and morality: The dialysis phenomenon. In The humanity of the ill: phenomenological perspectives, ed. V. Kestenbaum, 39-68. Knoxville: University of Tennessee Press.

47. Leder, D. 2002. Whose body? What body? The metaphysics of organ transplantation. In Persons and their bodies: Rights, responsibilities, relationships, ed. M. Cherry, 233264. Dordrecht: Kluwer Academic Publishers. 